\title{
EDITORIAL
}

\section{CHILDHOOD IN THE CROSSFIRE: HOW TO ENSURE A DIGNIFIED PRESENT AND FUTURE FOR CHILDREN AFFECTED BY WAR}

\author{
Ellen Policinski, Editor-in-Chief, and Kvitoslava Krotiuk, Legal Adviser and \\ Thematic Editor*
}

I just want to go back to a normal life, resume my training and become a builder one day, like my father.

Testimony by I. N., former child soldier ${ }^{1}$

Eglantyne Jebb, drafter of the Declaration on the Rights of the Child and founder of Save the Children, said: "All wars, just or unjust ... are waged against children." During armed conflict and other situations of violence, children are especially vulnerable to a myriad of risks that deprive them of the opportunity to fully experience childhood. ${ }^{3}$ They are often deprived of food, clean water, health care, and access to education; this is particularly troubling given the number of children who die of preventable illnesses, malnutrition, lack of safe shelter, or violence. Moreover, despite the protection afforded by international law, children are all too often drawn into hostilities-directly as fighters, or indirectly, separated from their families, detained, recruited, forcibly driven from their homes, killed, injured, sexually abused or exploited in other ways. ${ }^{4}$ In circumstances where survival becomes a daily struggle, children often lose any opportunity to study. Fortunately, children rarely give up their sense of hope, and their resilience should not be underestimated.

Children have been affected by war throughout history, and this is still true in today's conflicts, where we continue to see terribly high levels of suffering. Gender, age, ethnic and cultural background, disability, beliefs and other factors can exacerbate specific vulnerabilities in a given context. ${ }^{5}$ In light of this, more research is needed on the consequences that armed conflict has for children, as well as on the most suitable responses to their various needs and the challenges they face during and after armed conflict. For this reason, and as we have just marked the 30th anniversary of the Convention on the Rights of the Child (CRC), the Review has chosen to dedicate this issue to children and war.

* Thanks to Helen Durham, Monique Nanchen, Vanessa Murphy, Sai Sathyanarayanan Venkatesh, Mariana Citrinovitz, Siobhan Foran, Nicole Martins-Maag and Indu Nepal for their valuable feedback on an earlier draft. 


\section{Challenges faced by children in armed conflict: Children are not "miniature adults"}

There is a fundamental fact underlying the experience of children in armed conflict that is perhaps not as obvious as aid workers engaged in this area might assume: Children are not small grown-ups. They have their own particular needs, capacities and vulnerabilities during armed conflict. The International Committee of the Red Cross (ICRC) recognized this nearly two decades ago, stating:

[I]t cannot be denied that the needs of children are radically different from those of women, men and the elderly. Today children are still often regarded as miniature adults and are frequently at the mercy of a society or an environment which is not always willing to grant them the status they require: that of future adults. Showing better understanding of children merely means providing them with aid that is more consistent with their needs as developing individuals. ${ }^{6}$

In addition to providing children with adequate aid, it is crucial to respond to their current needs and to enable them to experience childhood.

In this issue of the Review, Monique Nanchen, the ICRC's Global Adviser on Children, emphasizes the need to involve children themselves in the design of humanitarian programming and outlines four priority issues of the ICRC's protection strategy on children: "children in detention, child recruitment [by armed forces and armed groups], the impact of conflict and violence on children's access to education, and family separation". She also mentions other issues such as sexual violence against children. ${ }^{7}$

Also in this issue, Dyan Mazurana, Anastasia Marshak and Kinsey Spears look at child marriage as one type of sexual and gender-based violence that occurs in humanitarian settings such as natural disasters and armed conflict. They advocate for common data collection tools to gather more information on

1 See "Testimonies of Former Child Soldiers in the Democratic Republic of the Congo" in this issue of the Review.

2 From a commemorative text about Eglantyne Jebb written by her sister, quoting Eglantyne twenty-five years after her death: "Toutes les guerres, disait Eglantyne, qu'elles soient justes ou injustes, sont livrées contre l'enfant" (authors' translation). Y. M., "Eglantyne Jebb: A Sister's Tribute", Revue International de la Croix-Rouge, Vol. 35, No. 414, 1953, p. 488.

3 More than one in ten children are affected by armed conflict globally. Ayesha Kadir, Sherry Shenoda, Jeffrey Goldhagen, Shelly Pitterman and Section on International Child Health, "The Effects of Armed Conflict on Children", Pediatrics, Vol. 142, No. 6, 2018.

4 Parts of this editorial are based on Ellen Policinski, "Children and War: Upcoming Review Edition", Humanitarian Law \& Policy Blog, 19 November 2019, available at: https://blogs.icrc.org/law-andpolicy/2019/11/19/children-and-war-upcoming-review-edition/ (all internet references were accessed in April 2020).

5 See, for example, Hugo Slim, "Impartiality and Intersectionality", Humanitarian Law \& Policy Blog, 16 January 2018, available at: https://blogs.icrc.org/law-and-policy/2018/01/16/impartiality-and-intersectionality/.

6 "Children and War", International Review of the Red Cross, Vol. 83, No. 844, 2001, p. 1164. On the particularities of caring for child victims of sexual violence, see Françoise Duroch and Catrin SchulteHillen, "Care for Victims of Sexual Violence, an Organization Pushed to Its Limits: The Case of Médecins Sans Frontières”, International Review of the Red Cross, Vol. 96, No. 894, 2014, p. 616.

7 See “Q\&A: The ICRC's Engagement on Children in Armed Conflict and Other Situations of Violence: In conversation with Monique Nanchen, Global Adviser on Children, ICRC”' in this issue of the Review. 
"the prevalence, incidence, trends, drivers, push and pull factors, decision-making processes and consequences" of child marriage, as well as children born of child marriages, in order to better tailor responses to each context. ${ }^{8}$

Children who are born during war know no other life. In addition to growing up amidst armed conflict, those born as a result of sexual violence face stigma and rejection in their communities, even as they grow into adulthood. In the words of one child born after her mother survived sexual violence during the conflict in Bosnia and Herzegovina, "twenty-six years later, both my mother and I still live with the stigma". 9 Local organizations sometimes play a significant role in addressing this stigma. For example, Foundation Rwanda provides funding for children born from rape during the 1994 Rwandan genocide and refers their mothers to psychological and medical services, as well as raising awareness about the ongoing consequences of the genocide. ${ }^{10}$

While stigma affects the lives of both children and their mothers, the role of fathers is often ignored. Recent research demonstrates that in exceptional circumstances, men who have fathered such children may wish to keep contact with the child and the woman, and may even try to reunite with them. ${ }^{11}$ Some authors argue that in particular circumstances, the father's involvement may help to secure a child's well-being. ${ }^{12}$

Children who are born in territory controlled by non-State armed groups can face additional hardships. In this issue, Kathryn Hampton examines the consequences of the failure to recognize birth certificates issued by non-State groups to children born in areas outside State control, calling on States to ensure recognition of these birth certificates under their obligation to ensure the right to recognition as a person before the law. ${ }^{13}$

Another aspect of children's lives that is disrupted by armed conflicts is education. As a fundamental element of a functioning society, education is an essential service, akin to electricity and clean water. It is considered as such by most children living in conflict-affected areas. Increasingly, protracted conflicts lead to a prolonged lack of access to education, raising questions about how to protect children and ensure that they have the possibility of continuing their education both during and after the conflict. ${ }^{14}$ Previously in the Review, Geoff Loane and Ricardo Fal-Dutra Santos looked at humanitarian responses aimed at re-establishing

8 See Dyan Mazurana, Anastasia Marshak and Kinsey Spears, "Child Marriage in Armed Conflict", in this issue of the Review.

9 Ajna Jusić, "I Am Generation Equality: 'I Am a Child Born out of Wartime Rape", UN Women, 18 November 2019, available at: www.unwomen.org/en/news/stories/2019/11/i-am-generation-equalityajna-jusic-forgotten-children-of-war.

10 See the Foundation Rwanda website, available at: https://foundationrwanda.org/.

11 Camile Oliveira and Eric Baines, “Children 'Born of War': A Role for Fathers?", International Affairs, Vol. 96, No. 2, 2020.

12 Ibid. It should be noted that Oliveira and Baines's research focused on the Acholi clan in Northern Uganda, where there is a particularly strong cultural identity of clanship on the parental side.

13 See Kathryn Hampton, "Born in the Twilight Zone: Birth Registration in Insurgent Areas", in this issue of the Review.

14 See ICRC, IHL and the Challenges of Contemporary Armed Conflicts, Geneva, 2019, Chap. 3, section 3 on "Access to Education", available in the "Reports and Documents" section of this issue of the Review. 
education services in conflict-affected areas and at the protection of education through programmatic responses with the participation of affected communities. ${ }^{15}$

Children are often separated from their families during armed conflict, leaving many of them unaccompanied. There are numerous examples of efforts to restore family links severed by war by ever-evolving means, from posters featuring photographs of family members to use of the media and the development of a centralized database, among other measures. ${ }^{16}$ Technologies designed to aid in restoring contact between separated family members and reuniting families continue to evolve today. ${ }^{17}$

A broad range of children's experiences during armed conflict can cause trauma, and humanitarians are increasingly aware of the need to address these "invisible wounds". In one article in this issue, the authors write about Rohingya communities in Myanmar and Bangladesh in order to examine the psychosocial consequences of armed conflict for children and youth, as well as some of the ongoing humanitarian responses promoting children's psychological and mental well-being. ${ }^{18}$

\section{The vulnerability-resilience paradigm}

Children might be particularly vulnerable in wartime, but there are also many examples of children's resilience when faced with armed conflict, both in developing survival strategies during and after conflict and in overcoming the traumas they experience. It has been argued that " $[\mathrm{t}]$ he notion of resiliency in children could easily become a new form of denial of trauma among children, whereby political systems evade responsibility for helping war-traumatized children". ${ }^{19}$ Contributions in this issue uncover the complex and ambivalent nature of children's experience that finds strength and resilience during traumatic events.

Children are not always victims of collateral damage - sometimes they are intentionally targeted. In her article in a recent issue of the Review examining the

15 Geoff Loane and Ricardo Fal-Dutra Santos, “Strengthening Resilience: The ICRC's Community-Based Approach to Ensuring the Protection of Education", International Review of the Red Cross, Vol. 99, No. 905, 2018.

16 See, for example, Monika Ampferl, "La recherche des Allemands prisonniers ou portés disparus au cours de la Seconde Guerre mondiale", International Review of the Red Cross, Vol. 81, No. 834, 1999, p. 394; Thierry Schreyer, "L'action de l'Agence centrale de recherches du CICR dans les Balkans durant la crise des réfugiés kosovars", International Review of the Red Cross, Vol. 82, No. 837, 2000, p. 52; Maarten Merkelbach, "Reuniting Children Separated from Their Families after the Rwandan Crisis of 1994: The Relative Value of a Centralized Database", International Review of the Red Cross, Vol. 82, No. 838, 2000, p. 362.

17 For more on this, see the upcoming issue of the Review on "Digital Technologies and War".

18 See Rochelle L. Frounfelker, Nargis Islam, Joseph Falcone, Jordan Farrar, Chekufa Ra, Cara Antonaccio, Ngozi Enelamah and Theresa S. Betancourt, "Living through War: Mental Health of Children and Youth in Conflict-Affected Areas", in this issue of the Review.

19 Atle Dyregrov, Leila Gupta, Rolf Gjestad and Eugénie Mukanoheli, “Trauma Exposure and Psychological Reactions to Genocide among Rwandan Children", Journal of Traumatic Stress, Vol. 13, No. 1, 2000, p. 14, cited in Hélène Dumas, "When Children Remember: A History of the Tutsi Genocide through the Eyes of Children (1994-2006)”, International Review of the Red Cross, Vol. 101, No. 910, 2019, p. 56. 
accounts of children who survived the genocide against the Tutsi in Rwanda, Hélène Dumas observes that

in Rwanda, as during the genocides of Armenians and of European Jews, the intention to exterminate became apparent as soon as the systematic mass murder of women and children began. Their deaths sever the line of descent forever, breaking the link between generations. Children are the primary targets of any genocide. ${ }^{20}$

On the one hand, the voices of child survivors portray children's vulnerability in being exposed to violence and lack of food and shelter. On the other hand, one sees a sense of resilience in survivors developed by forming a "micro-society" and taking responsibility for other children amid horrendous suffering.

The concept of resilience can be understood in different ways. For example, French neuropsychiatrist Boris Cyrulnik speaks about resilience from an angle of post-war (post-traumatic) experience:

Resilience is not a case of returning to a previous state, because returning to a previous state is healing, whereas resilience is a matter of getting back on the right track, although you can't refer to it as "normal" development, because you never forget the trauma. When you've been a child caught up in war ... you don't ever forget. However, you are no longer a slave to your memories because you've managed to make something out of those experiences, and that's the next chapter. ${ }^{21}$

\section{How does law protect children?}

Over time, norms of international law have arisen to address some of the cruelties visited upon children, both in peacetime and in wartime. A number of branches of international law include rules aimed at protecting children, including international human rights law, international refugee law and international humanitarian law (IHL). Indeed, the historical importance of the contribution of the 1949 Geneva Conventions and their Additional Protocols to the protection of children in armed conflict is often forgotten. The Geneva Conventions contained the first universally ratified protection for children, ${ }^{22}$ and the Additional Protocols set out the first prohibition on child recruitment, prior to the CRC and its Optional Protocol on the Involvement of Children in Armed Conflict. ${ }^{23}$

Under IHL, children benefit from special respect and protection as a way to respond to their specific needs, including access to education, food and health care, reunification with their families when they have been separated, and separation from adults while deprived of liberty, as well as age-appropriate treatment

21 "Interview with Boris Cyrulnik", International Review of the Red Cross, Vol. 101, No. 910, 2019, p. 23.

22 Geneva Convention IV (GC IV), Arts 24, 50.

23 Additional Protocol I (AP I), Art. 77; Additional Protocol II (AP II), Art. 4(3). 
while detained. This is true in both international armed conflicts (IACs) ${ }^{24}$ and noninternational armed conflicts (NIACs), ${ }^{25}$ and this special protection afforded to children has been recognized as customary international law. ${ }^{26}$ These specific rules complement the general protections that children benefit from as civilians, including protection from direct attack. ${ }^{27}$ Additionally, children are protected under IHL from being recruited into armed forces or armed groups ${ }^{28}$ (although the minimum age of recruitment is dependent on the treaties to which a given State is party) and must not be allowed to take part in hostilities. ${ }^{29}$ Even if children do take part in hostilities, they still benefit from special protections. ${ }^{30}$ All in all, more than twenty-five articles of the four Geneva Conventions and their Additional Protocols specifically concern children. ${ }^{31}$

The roots for these protections can be found in older bodies of law, including religious legal systems. These legal systems can play a significant role in influencing the behaviour of parties to armed conflict today. In particular, a number of parties to current armed conflicts have expertise in and look to the rules of the Islamic law of war as they fight. In this issue of the Review, Ahmed Al-Dawoody and Vanessa Murphy accordingly set out and compare how IHL rules and Islamic law rules protect children in armed conflict, "bridging the discourses between Islamic law and IHL protections of children in order to find mutual reinforcement". ${ }^{32}$

International human rights law complements IHL norms protecting children, in particular the CRC and its Optional Protocol on the Involvement of Children in Armed Conflict. ${ }^{33}$ The Review has followed these legal developments closely, publishing several articles on legal protections for children in armed conflict. ${ }^{34}$ When the Optional Protocol to the CRC was adopted in 2000, Daniel Helle detailed the background of the negotiations in the journal, calling it a

24 GC IV, Arts 14, 17, 23, 24, 38(5), 50, 82, 89, 94, 132; AP I, Art. 70(1).

25 AP II, Art. 4(3).

26 Jean-Marie Henckaerts and Louise Doswald-Beck (eds), Customary International Humanitarian Law, Vol. 1: Rules, Cambridge University Press, Cambridge, 2005 (ICRC Customary Law Study), Rules 135137, available at: https://ihl-databases.icrc.org/customary-ihl/eng/docs/vl.

27 See AP I, Art. 51; ICRC Customary Law Study, above note 26, Rule 1.

28 AP I, Art. 77(2); AP II, Art. 4(3)(c); ICRC Customary Law Study, above note 26, Rule 136.

29 AP I, Art. 77(2); AP II, Art. 4(3)(c); ICRC Customary Law Study, above note 26, Rule 137.

30 Article 77 of AP I and Article 4(3)(d) of AP II affirm that captured children who have taken part in hostilities continue to benefit from entitlement to special care, such as age-appropriate food, health care, and access to education. In addition, the 2007 Paris Principles on Children Associated with Armed Forces and Armed Groups (available at: www.refworld.org/docid/465198442.html) set out important standards on support and reintegration for these children.

31 See also "Children and War", above note 6, p. 1165.

32 See Ahmed Al-Dawoody and Vanessa Murphy, "International Humanitarian Law, Islamic Law and the Protection of Children in Armed Conflict", in this issue of the Review.

33 Optional Protocol to the Convention on the Rights of the Child on the Involvement of Children in Armed Conflict, UN Doc. A/RES/54/263, 25 May 2000 (entered into force 12 February 2002). See also Helen Durham, "How Can We Meet Children's Needs and Rights in Humanitarian Situations?", speech given on the Annual Day of Discussion on the Rights of the Child, 37th Human Rights Council, 5 March 2018, available at: www.icrc.org/en/document/how-can-we-meet-childrens-needs-and-rights-humanitariansituations.

34 See, for example, Denise Plattner, "La protection de l'enfant dans le droit international humanitaire", International Review of the Red Cross, Vol. 66, No. 747, 1984; Sandra Singer, "La protection des enfants dans les conflits armés", International Review of the Red Cross, Vol. 68, No. 759, 1986. 
"welcome initiative" in line with the policies of the International Red Cross and Red Crescent Movement. ${ }^{35}$

Similarly, this issue follows recent developments related to international legal protections for children. Diane Marie Amann describes the process that led to the International Criminal Court (ICC) Office of the Prosecutor's Policy on Children, showing the Office of the Prosecutor's focus on crimes against children. After detailing the policy, Amann concludes that "States, international organizations and civil society must also work for prevention in spheres other than the ICC, and by means other than criminal prosecution". ${ }^{36}$

While the current multilateral environment might not be conducive for consensus on new treaties, we continue to see meaningful advocacy and policy efforts that are strengthening protection of children in armed conflict, such as the Safe Schools Declaration and the Guidelines for Protecting Schools and Universities from Military Use during Armed Conflict, among other soft-law instruments. ${ }^{37}$ Bede Sheppard looks at why such efforts to deter military use of schools are important, pointing out that military use of schools may "place students at risk of attack and interfere with their education". ${ }^{38}$

Protections for children are also enshrined in law at the regional level. An important example of this is the African Charter on the Rights and Welfare of the Child, adopted by the Organization of African Unity (now the African Union) in 1990, which covers a wide range of civil, political, economic, social and cultural rights for children. ${ }^{39}$ Benyam Dawit Mezmur explores the monitoring and implementation of the Charter in this issue, observing:

The efforts to create a world fit for children, including for those affected by armed conflict, remain a work in progress. Increasingly, regional organizations, prime among them the African Union and its organs, are being asked to play a more meaningful role in pushing for the realization of the rights and protections of children in armed conflict. ${ }^{40}$

Domestic law is also an important way of ensuring compliance with international norms. For an in-depth look at developments in national legislation and jurisprudence implementing norms aimed at strengthening the protection of

35 Daniel Helle, "Optional Protocol on the Involvement of Children in Armed Conflict to the Convention on the Rights of the Child", International Review of the Red Cross, Vol. 82, No. 839, 2000, p. 808.

36 See Diane Marie Amann, "The Policy on Children of the ICC Office of the Prosecutor: Toward Greater Accountability for Crimes against and Affecting Children", in this issue of the Review.

37 Global Coalition to Protect Education from Attack (GCPEA), Safe Schools Declaration, available at: www. protectingeducation.org/sites/default/files/documents/safe_schools_declaration-final.pdf; GCPEA, Guidelines for Protecting Schools and Universities from Military Use during Armed Conflict, available at: www.protectingeducation.org/sites/default/files/documents/guidelines_en.pdf.

38 See Bede Sheppard, "Keeping Schools Safe from the Battlefield: Why Global Legal and Policy Efforts to Deter the Military Use of Schools Matter", in this issue of the Review.

39 African Charter on the Rights and Welfare of the Child, CAB/LEG/24.9/49, 11 July 1990 (entered into force 29 November 1999).

40 See Benyam Dawit Mezmur, “Taking Measures without Taking Measurements? An Insider's Reflections on Monitoring the Implementation of the African Children's Charter in a Changing Context of Armed Conflict", in this issue of the Review. 
children in armed conflict both regionally and domestically over the past five years, readers can consult the thematic update on national implementation of IHL, prepared by the ICRC's Advisory Service on IHL. ${ }^{41}$

Despite legal prohibitions on children's participation in hostilities at the international, regional and domestic levels, children continue to be used in various capacities during armed conflict by States and armed groups alike. Many authors have examined various aspects of this phenomenon in previous issues of the Review. For example, in her article looking at the motivations of adolescents who have volunteered to join armed forces or armed groups based on research conducted by the Quaker United Nations Office and the International Labour Organization, Rachel Brett argued that " $[\mathrm{t}] \mathrm{o}$ counter the problem of child recruitment with any hope of lasting success, it is necessary to address the root causes in terms of ... war, poverty, education, employment and the family", noting that "this presents a challenge of monumental proportions". ${ }^{42}$

Elsewhere in past issues, María Teresa Dutli provided insights into the legal status and treatment of captured children associated with armed forces or armed groups in both IACs and NIACs, ${ }^{43}$ and Naïri Arzoumanian and Francesca Pizzutelli questioned the criminal responsibility of children associated with armed forces once captured, particularly in Liberia, the Democratic Republic of the Congo (DRC), Rwanda and Sierra Leone. ${ }^{4}$

In this issue, Pascal Bongard and Ezequiel Heffes explore some of the challenges of working with non-State armed groups to ensure compliance with IHL norms protecting children. They point out that "violations against children do not simply happen; they are the result of complex mechanisms entailing a variety of explanations", going on to explore some of the possible factors driving behaviour that violates international norms protecting children via examples from Geneva Call's experience in different conflict contexts. ${ }^{45}$

\section{Passive victims, agents of change, and child "terrorists": How do we see children in armed conflict?}

Historically, and even today, children have been portrayed as passive victims in war. We can see this reflected in the pages of the Review itself. In the early twentieth

41 See "What's New in Law and Case Law around the World? Protection of Children in Armed Conflict" in this issue of the Review.

42 Rachel Brett, "Adolescents Volunteering for Armed Forces or Armed Groups", International Review of the Red Cross, Vol. 85, No. 852, 2003, p. 864.

43 María Teresa Dutli, "Enfants-combattants prisonniers", International Review of the Red Cross, Vol. 72, No. $785,1990$.

44 Naïri Arzoumanian and Francesca Pizzutelli, "Victimes et Bourreaux: Questions de responsabilité liées à la problématique des enfants-soldats en Afrique", International Review of the Red Cross, Vol. 85, No. 852, 2003.

45 See Pascal Bongard and Ezequiel Heffes, "Engaging Armed Non-State Actors on the Prohibition of Recruiting and Using Children in Hostilities: Some Reflections from Geneva Call's experience", in this issue of the Review. 
century, the Review simply described the plight of children caught up in war ${ }^{46}$ and recounted humanitarian activities on behalf of children. ${ }^{47}$ A 2001 article in the Review states: "All too often children are helpless, first-hand witnesses of atrocities committed against their parents or other family members." 48 Overall, children were portrayed as victims of war and passive recipients of humanitarian aid.

As the Review has evolved, we can see more in-depth examination of the cruelty children suffer in war, and how it drives humanitarian action. This has included the plight of children separated from their families by the Rwandan genocide; ${ }^{49}$ the human cost exacted on civilians by the wars in Iraq, including the distinct suffering of women and children; ${ }^{50}$ the impacts of the Boer War in South Africa, which disproportionately fell upon children; ${ }^{51}$ and more recently the heavy costs borne by family members of detainees, including children. ${ }^{52}$ The journal has also explored the humanitarian response to the suffering of children, such as the British Red Cross response to young migrants in the Calais "jungle". 53

Perhaps as a consequence of the perception of children as inexperienced, innocent and dependent, inhumanity directed at children tends to inspire more humanitarian sentiment than the same cruelty directed at adults. Humanitarian organizations have even sometimes taken advantage of the perception of children as innocent victims, in some cases intentionally using their images in campaigns to pull at the heartstrings of potential donors and others. ${ }^{54}$

In contrast, there are prominent examples of children, far from being only passive victims, who are telling their own wartime stories. Perhaps the best known of these is the diary of Anne Frank, written while her family was in hiding during World War II. ${ }^{55}$ More recent examples include Zlata Filipovićs6 and Malala Yousafzai, who demonstrate how children can also be inspiring agents of

46 See, for example, Joseph Jakobkiewicz, "L’odyssée des enfants perdus en Sibérie”, Revue Internationale de la Croix-Rouge, Vol. 7, No. 73, 1925.

47 "Les secours de la Croix-Rouge aux enfants de réfugiés", Bulletin International des Societés de la CroixRouge, Vol. 47, No. 187, 1916.

48 "Children and War", above note 6, p. 1164.

49 See, for example, Maarten Merkelbach, "Reuniting Children Separated from Their Families after the Rwandan Crisis of 1994: The Relative Value of a Centralized Database", International Review of the Red Cross, Vol. 82, No. 838, 2000.

50 Nasir Ahmed Al Samaraie, "Humanitarian Implications of the Wars in Iraq", International Review of the Red Cross, Vol. 89, No. 868, 2007.

51 Elizabeth van Heyningen, "The South African War as Humanitarian Crisis", International Review of the Red Cross, Vol. 97, No. 900, 2016.

52 Megan Comfort, Tasseli McKay, Justin Landwehr, Erin Kennedy, Anupa Bir and Christine Lindquist, "The Costs of Incarceration for Families of Prisoners", International Review of the Red Cross, Vol. 98, No. $903,2018$.

53 Debbie Busler, "British Red Cross Response to Young Migrants in Calais, France", International Review of the Red Cross, Vol. 99, No. 904, 2018.

54 See, for example, Neide Fehrenbach and Davide Rodogno, "'A Horrific Photo of a Drowned Syrian Child': Humanitarian Photography and NGO Media Strategies in Historical Perspective", International Review of the Red Cross, Vol. 97, No. 900, 2015.

55 Anne Frank, Anne Frank: The Diary of a Young Girl, Bantam Books, New York and Toronto, 1993.

56 Zlata Filipović, Zlata's Diary: A Child's Life in Sarajevo, Penguin Books, New York, 1995. 
change. ${ }^{57}$ In her article for this issue of the Review, Helen Berents challenges the view of children as victims or bystanders, using children's own memoirs to demonstrate that they actively exercise "tactical agency" to negotiate life in a war zone. ${ }^{58}$ Considering the narratives of children themselves is important to show that children exercise agency, playing an active role during armed conflicts. They do not simply "endure", but can contribute to making things better.

In the same vein, this issue opens with testimonies from former child soldiers in the DRC, bringing their voices to the fore and allowing children affected by armed conflict to speak for themselves. The story they tell is one of difficult choices they make in extreme circumstances, and also of stigmatization after having demobilized. To quote one boy:

I spend my days with other young people in the neighbourhood, but no one knows that I was a fighter. I wouldn't like them to know, because when you have been a fighter, you risk being treated as an outcast and slandered in the community. Some people even accuse you of things you haven't done. ${ }^{99}$

Today, the public perception of some children in humanitarian crises around the world appears to be shifting. Although horrific images of children like Alain Kurdi $^{60}$ and Omran Daqneesh ${ }^{61}$ still catch the public attention, there is also a counter-narrative that casts children as a potential security threat, whether they are refugees and migrants in search of a better chance at life or are caught up in armed conflict or other crises. This is particularly apparent in the treatment of children involved in so-called "terrorist" groups. ${ }^{62}$ Helen Durham observes that "children who fall into certain categories or are associated with certain labels categories such as 'migrant' or 'girl', and labels such as 'violent extremist' - are often at greater risk of facing lower standards of implementation of existing legal protections". ${ }^{63}$ This issue of the Review contains an interview with Mira Kusumarini, who works on the reintegration of children formerly associated with armed groups in Indonesia. She highlights that empathy is the driving force behind successful reintegration - "not only the children's own empathetic skills, but it was also important for the social workers [working with these children] to

57 Malala Yousafzai and Christina Lamb, I Am Malala: The Girl Who Stood Up for Education and Was Shot Down by the Taliban, Little, Brown and Company, New York, 2013.

58 See Helen Berents, “'This Is My Story’: Children's War Memoirs and Challenging Protectionist Discourses", in this issue of the Review.

59 See "Testimonies of Former Child Soldiers in the Democratic Republic of the Congo" in this issue of the Review.

60 See Helena Smith, "Shocking Images of Drowned Syrian Boy Show Tragic Plight of Refugees", The Guardian, 2 September 2015, available at: www.theguardian.com/world/2015/sep/02/shocking-imageof-drowned-syrian-boy-shows-tragic-plight-of-refugees.

61 See Karem Shaheen, "I Filmed the Syrian Boy Pulled from the Rubble - His Wasn't a Rare Case", The Guardian, 18 August 2016, available at: www.theguardian.com/world/2016/aug/18/i-filmed-the-syrianboy-pulled-from-the-rubble-his-wasnt-a-rare-case.

62 See Sandra Krähenmann and Paulien Vandendriessche, "From Child Soldier to Child 'Terrorist': Safeguarding Innocence from Counter-terrorism", Humanitarian Law \& Policy Blog, 20 November 2019, available at: https://blogs.icrc.org/law-and-policy/2019/11/20/child-soldier-counter-terrorism/.

63 H. Durham, above note 33. 
work on their empathetic skills in order to understand the children's situation" as well as that of the community. She also highlights that the narratives in media coverage can be detrimental. ${ }^{64}$ This can be seen elsewhere, where the narrative of "radicalization" associated with initiatives aimed at countering or preventing violent extremism can be counterproductive and lead to stigmatization.

This begs the question: in an age where it is perhaps not politically popular to provide all children with the protection they are both morally and legally entitled to, how can we ensure that their needs and rights are fulfilled?

Also in this issue are several articles that are not related to the main theme but are nonetheless significant contributions to the debate on humanitarian law, action and history. Julie Freccero et al. look at "Safer Cash in Conflict: Exploring Protection Risks and Barriers in Cash Programming for Internally Displaced Persons in Cameroon and Afghanistan"; James Houlihan looks to the distant past in "Lex Innocentium (697 AD): Adomnán of Iona-Father of Western Jus in Bello"; Suzannah Linton writes on "Deciphering the Landscape of International Humanitarian Law in the Asia-Pacific"; and lastly, Duncan McLean highlights the ever-present danger of attacks on health care in "Medical Care in Armed Conflict: Perpetrator Discourse in Historical Perspective". 